\title{
Baldwin Hills Scenic Overlook Methods
}

\section{Firm Liaison:}

Ruth Stafford

Landscape Designer \& Associate

Wallace Roberts \& Todd

This case study was produced in 2010 as part of the Landscape Architecture Foundation's Landscape Performance Series pilot. Firms submitted their projects, and LAF staff worked with firm representatives to document the project and its environmental, social, and economic benefits.

To cite:

Landscape Architecture Foundation. "Baldwin Hills Scenic Overlook Methods." Landscape Performance Series. Landscape Architecture Foundation, 2010. https://doi.org/10.31353/cs1471

The full case study can be found at:

https://landscapeperformance.org/case-study-briefs/baldwin-hills-scenic-overlook 


\section{Baldwin Hills Scenic Overlook Methodology for Landscape Performance Benefits}

- Saves approximately 4.2 million gallons of potable water annually (enough to supply 33 single-family households) through the use of water-efficient native plants and limited areas of irrigated landscape. This saves about $\$ 14,000$ annually in water costs.

These benefits involved a series of calculations:

1. Potential irrigation water use of all the installed landscape plantings was estimated by the methodology outlined in LEED Water Efficiency Credits for Reduced Landscape Water Use (Assumptions: species factor $=0.3$; density factor $=1.0$; microclimate factor $=1.0$; irrigation efficiency $=0.7$ ).

2. The potential water saved was adjusted based on the amount of unirrigated plantings versus total area of installed vegetation (areas determined by area take-offs from CAD drawings).

3. Household water use comparisons were based on data of household water use from the City of Los Angeles Department of Water \& Power 2005 Urban Water Management Plan.

4. Money saved was based on non-residential metered water rates for the Golden State Water Company, Culver City Customer Service Area.

- Reduced waste, saved between $\$ 4,000$ and $\$ 10,000$, and prevented the release of over 16 tons of carbon dioxide into the atmosphere by recycling approximately 70 cubic yards of concrete, equivalent to about 7 large concrete mixer trucks.

These benefits involved a series of calculations:

1. Area of recycled concrete pavement was determined by area takeoffs from CAD drawings. Equivalent volume (cubic yards) of recycled concrete was estimated by multiplying the area of recycled concrete by the corresponding thickness of the pavement, climbing stairs, and retaining walls as indicated in construction drawings.

2. Volume of concrete trucks was researched via online searches for typical volumes of contemporary concrete mixer trucks (about 10 cubic yards per truckload).

3. Cost savings was estimated by determining the potential cost of equivalent area of concrete paving steps needed in lieu of recycled concrete used for the climbing trail and other pavement applications. Price quotes for large cast concrete pavers (similar size to recycled concrete applications) were obtained for a range of colors and finishes from a nationally-known manufacturer. The price range obtained reflects the range of products available at different costs. The costs represent just the material cost, without shipping.

4. Estimates of carbon dioxide emissions saved were based on greenhouse gas emissions data for Portland cement concrete summarized in Table 5-8 (page 111) in Materials for Sustainable Sites, by Meg Calkins, 2009, John Wiley \& Sons.

- Accommodates several hundred visitors daily during morning and evening hours for hiking and other passive recreation, as well as fitness workouts.

Visitation data were provided by California State Parks staff for visitor center counts and observation of users in the park landscape, including climbing trail. 
- Accommodates additional visitors at the Visitor Center, with a daily average of $\mathbf{4 0 0}$ visitors in spring, 500 in summer, 250 in fall, and 200 in winter.

Visitation data were provided by California State Parks staff for visitor center counts and observation of users in the park landscape, including climbing trail.

- Provides 57 acres of parkland in a park-deficient urban area with barely 1 acre of parkland per 1,000 residents. Over a million people live within a 5-mile radius.

This information was provided by the client, California State Parks. Parkland level of service (number of acres per 1,000 residents) is determined by summing the public parkland acreage in a given area and expressing it as a ratio per 1,000 residents (based on population size in the same area). These data are commonly available from city/county park and recreation departments or planning departments. For example, an area with a population of 500,000 and 1,500 acres of parkland has a level of service of 3 acres per 1,000 residents. Population within a radius is typically estimated using GIS mapping and available census data. 